\title{
Long-run consequences of the pandemic debt
}

\author{
Gene Tunny ${ }^{1}$
}

\section{Abstract}

Future Australian federal governments will face difficult choices when they need to address the massive increase in public debt due to the Covid-19 pandemic and the 2008-09 Global Financial Crisis (GFC). Future governments will need to either increase taxes or make difficult spending cuts to improve budget balances and get the debt-to-GDP ratio under control. The huge challenge facing future governments is illustrated using an Australian government Budget Debt Projections Model and Monte Carlo simulations.

The Covid-19 pandemic has seen hitherto unexpectedly large Australian government deficits and gross federal debt being placed on a trajectory to exceed $\$ 1$ trillion, but there is a large degree of insouciance regarding the long-run fiscal challenge. The government appears relaxed and credit rating agencies seem undisturbed, although that could change, particularly as the economic and fiscal costs from the new Delta variant mount.

One reading of the 2021 Intergenerational Report (IGR) by the Treasury (2021) is that the debt can be easily managed over the next 40 years, as net debt will only be 34 per cent of GDP by 2060-61, after peaking at 41 per cent in 2024-25 and falling to 28 per cent in $2044-45 .^{2}$ That is likely highly optimistic, as demonstrated in this article. The future is highly uncertain, as the wildly varying projections of

\footnotetext{
1 Adept Economics, Brisbane; contact@adepteconomics.com.au. The author acknowledges the research assistance provided by Taylor-Rose Hull. The modelling results presented in this article are based on Australian government budget estimates that were current in July 2021.

2 For instance, see Kirchner (2021).
} 
future budget balances and debt measures in different vintages of the $I G R$ reveal. Credit to the Treasury for being candid about the deficiencies of such mechanical projection modelling, which ends up being dependent on contentious assumptions.

Rather than accepting one future time path for budgets and debt, it would seem prudent to consider a range of scenarios based on plausible developments in the global and domestic economies. In this paper, we use a slimmed-down, fit-forpurpose version of the Australian Government's $I G R$ model to explore these various scenarios and to assess their implications for future Australian government budget policies. The Treasury should consider undertaking similar scenario or simulation analysis in future iterations of the $I G R$, so it presents not just 'point estimates' but also ranges of possible outcomes.

Such scenarios include the so-called Great Demographic Reversal (GDR) that is expected to result in much higher real (and hence nominal) interest rates. Also, we should consider the potential for Pandemic 2.0 or Global Financial Crisis 2.0 within the next 40 years, either of which would lead to another massive step-up in debt.

The IGR has emphasised the importance of governments having 'fiscal room' or 'fiscal space' to respond to crises, which is an implicit recognition that crises bring about huge increases in debt-something that is not included in mechanical spreadsheet projection models such as that underpinning the IGR. It is important to do so, given how rapidly we have seen debt take off during previous crises.

For example, in the five years up to 2007-08, Australian government gross borrowings were in the range of \$50-55 billion, but five years later, in 2012-13, borrowings were $\$ 257$ billion-an increase from around 5 per cent to 17 per cent of GDP. Regarding the debt impact of the pandemic, consider that borrowings are projected to increase from $\$ 542$ billion in 2018-19 to \$1.134 trillion in 2023-24an increase from around 28 per cent to 50 per cent of GDP. It would be realistic and prudent to consider it likely that Australia will experience another economic crisis over the next four decades (the time frame of the IGR), and the possibility of this should be reflected in long-run projections models such as that used in the IGR.

As the late Rudiger Dornbusch (1986, p. 182) observed: '[T] ransitory deficits, if they are large and persistent, do have a significant long-run impact on the required noninterest surpluses that must ultimately be generated to sustain the government's solvency.' Hence, it is important to consider scenarios in which the current long-run trajectory of the debt is shocked by new transitory deficits. 


\section{What has happened to the debt?}

Historically, Australia has seen several periods of debt accumulation followed by periods of fiscal consolidation. Net debt is a well-known indicator of a government's financial strength. It differs from gross debt as it is equal to gross debt less financial assets such as cash investments and debt securities the government owns.

By 1980, net debt in Australia had reduced by approximately 10 per cent of GDP, with the remainder of the 1980s seeing increased fiscal consolidation. However, in the early 1990s recession, the budget returned to sizeable deficits. 'The ratio of general government net debt to GDP in Australia rose to around 20 percent in the mid 1980s and 25 percent in the mid 1990s' (Gruen \& Sayegh, 2005). In 1995-96, net debt in Australia reached a peak of 18.5 per cent of GDP.

The recovery from the recession began in the September quarter of 1991. Under the Howard Government and Treasurer Peter Costello, the 1996 budget committed to reducing the underlying deficit of 3.5 per cent of GDP to 0.5 per cent over three years, reducing public sector lending, the pressure of the current account deficit and returning the budget to a structural surplus (Bongiorno, 2019). Consequently, Australia's financial position improved from the mid-1990s and gross debt steadily declined as a share of GDP (Di Marco et al., 2019). Net debt as a proportion of GDP declined to -3.8 per cent in 2007-08 because of budget surpluses and asset sales (Gruen \& Sayegh, 2005).

The Commonwealth Government ran surpluses from 2003 until 2008. In 2008, the GFC hit and Australia's net debt position reduced from -3.8 per cent of GDP to a high of 6.0 per cent in 2012-13. In 2008-09, government support for the economy was $\$ 52$ billion, or 4 per cent of GDP. It took 10 years to return to a budget balance and the government planned to pay that back in 2020-21.

Table 1. Australian government debt metrics

\begin{tabular}{|l|r|r|r|r|}
\hline Selected years & Debt $\mathbf{( \$ m )}$ & Debt (\% of GDP) & Net debt (\$m) & Net debt (\% of GDP) \\
\hline $2024-25$ & $1,199,000$ & 50.0 & 980,561 & 40.9 \\
\hline $2019-20$ & 684,298 & 34.5 & 491,217 & 24.7 \\
\hline $2014-15$ & 368,738 & 22.7 & 245,817 & 15.1 \\
\hline $2009-10$ & 147,133 & 11.3 & 47,874 & 3.7 \\
\hline $2004-05$ & 55,151 & 6.0 & 15,604 & 1.7 \\
\hline $1999-2000$ & 75,536 & 11.4 & 57,661 & 8.7 \\
\hline $1994-95$ & 105,466 & 21.3 & 83,492 & 16.9 \\
\hline $1989-90$ & 48,399 & 12.0 & 16,915 & 4.1 \\
\hline $1984-85$ & 54,420 & 23.2 & 21,896 & 9.3 \\
\hline
\end{tabular}

Source: The Treasury (2021, pp. 365-66). 
As a result of Covid-19, Australia entered its first recession since 1991, according to the definition of two consecutive negative quarters. By June 2020, Australia’s GDP contracted by a record 7 per cent following a decline by 0.3 per cent in the March quarter. Federal Treasurer Josh Frydenberg provided a large stimulus, with the 2020-21 budget anticipating the cash deficit would reach 11 per cent of GDP. After the 2021-22 budget, Australia's net debt is expected to increase to $\$ 617.5$ billion, or 30 per cent of GDP. It is projected to continue growing, to $\$ 980.6$ billion or 40.9 per cent of GDP by mid-2025 (Guay et al., 2021). However, this remains low by international standards. According to the Treasurer, the Covid-19 recession will see Australia's deficit reach $\$ 161$ billion in $2020-21$, improving to $\$ 106.6$ billion in 2021-22, before improving further to $\$ 56$ billion in 2024-25.

Australia's large debt has increased interest payments, which are forecast to reach $\$ 21$ billion by 2024-25. However, in Australia, S\&P Global found a 3-percentagepoint lift in interest rates would barely increase the federal government's interest bill over the next two years (Wright, 2021). This is because so much debt has been borrowed at low interest rates that are locked in for several years. The 2021-22 Australian budget reported:

In the period between 20 March 2020 and 3 May 2021, the Australian Office of Financial Management (AOFM) has issued \$281.6 billion in Treasury Bonds, with a weighted average tenor of 9.4 years and a weighted average issuance yield of only 0.88 per cent. (Frydenberg \& Birmingham, 2021, p. 91)

Partly because of this, there is a large amount of complacency around Australian government debt. Illustrative of such complacency, the Grattan Institute has noted there has never been a cheaper time to borrow for necessary economic stimulus, urging Australians '[d]on't worry about the debt' (Wood \& Crowley, 2020).

\section{What did the IGR say would happen to the debt?}

According to Treasury's 2021 Intergenerational Report, while Australia's economic recovery is well advanced, some effects from the Covid-19 economic downturn will persist for years. As stated in the report, net debt is projected to peak at 40.9 per cent of GDP in 2024-25, before falling to 28.2 per cent of GDP in 2044-45 and then increasing to 34.4 per cent of GDP by 2060-61 (The Treasury, 2021, p. xi).

The IGR has faced criticism as forecasts assume they will not be interrupted by ever-changing realities and events into the future. According to business commentator Terry McCrann (2021), 'if you read any of the IGR you will see assumptions page after page'. He outlines that Treasury modelling in the IGR assumes net migration of 235,000 people every year without interruption and productivity output per 
worker to remain at 1.5 per cent until 2060 because it is favourable for the Treasury. It is outlined in the report that 'all projections are inherently uncertain and are unlikely to unfold as outlined in this report'. The 2021 IGR states that the budget is projected to stay in deficit for each of the 40 years until 2060-61, with the stated cause of those deficits being excessive growth in government spending.

It is reported that pressures of demographic change from an ageing population are likely to impose on future government spending. Spending on individuals is predicted to almost double, with an increase of 73 per cent. Total payments are projected to grow at a slower rate than previous years, of 2.5 per cent over the next 40 years, with total payments of 3.4 per cent. This is possibly attributed to lower projected population growth in the future. As outlined in the IGR, Australia's population has grown at an annual average rate of 1.4 per cent over the past 40 years. However, Covid-19 is expected to reduce population growth to a low of 0.1 per cent in 2020-21. It can be estimated that population growth over the next 40 years will be 1.0 per cent per annum (The Treasury, 2021, p. 13).

According to the Sydney Morning Herald's economics editor Ross Gittins (2021), only part of this increase is due to the ageing population; also in play is the higher cost of better-quality health care and aged care. Projections assume that Australia will be getting new tax cuts in each of the 15 years up to 2061, so the tax-to-GDP ratio does not exceed 23.9 per cent, and interest payments are expected to account for three-quarters of the budget deficit in 2060-61.

\section{The 2021-22 budget and IGR are already out of date due to lockdowns}

It only took until July 2021, when this article was written, for the 2021-22 budget, handed down in May, and for the $I G R$, published in late June 2021, to be significantly out-of-date, with larger and longer Covid-related restrictions implemented in some capital cities.

In June 2021, after Melbourne's most recent lockdown was extended, the federal government brought in $\$ 500$ payments that were to be consistently applied in future Covid-19 hotspots. In mid-July, the Morrison Government announced increased weekly payments for households and boosted business cashflow to get them through extended lockdowns. Treasury officials have estimated that the recent Sydney lockdowns have cost $\$ 700$ million a week (Tingle \& Elton, 2021).

Recently, the federal Treasurer announced that from week four of a lockdown due to a Commonwealth declaration of a hotspot, a Covid-19 disaster payment will increase from $\$ 500$ to $\$ 600$ each week if a person has lost 20 hours or more of work a week or $\$ 325$ to $\$ 375$ each week if a person has lost between eight and 20 hours of 
work (Frydenberg, 2021b). The Commonwealth will also fund 50 per cent of a new small and medium-sized business support payment to be implemented by Service NSW. Between $\$ 1,500$ and $\$ 10,000$ will be provided each week for businesses with a turnover of less than $\$ 50$ million.

This additional Covid-19 disaster payment is on top of the Commonwealth Government's previous JobKeeper and JobSeeker support. Primary sectors affected by the current restrictions include hospitality, retail and construction. Nearly half a million workers have qualified for Covid-19 disaster payments. Services Australia has stated that 518,000 claims for the Covid-19 disaster payment from people in New South Wales have been granted (Davies \& Visontay, 2021).

The government originally estimated payments would cost around $\$ 500$ million a week, which was before Victoria and South Australia went into lockdown. In New South Wales, 386,000 people have applied for the $\$ 600$-a-week payment and more than 83,500 have been granted the smaller payments. At present, the total amount paid out by the Commonwealth Government to NSW workers since 1 July is $\$ 219$ million and is expected to rise sharply.

In total, this would amount to approximately $\$ 4$ billion in payments over the six weeks. Now, at the end of July, Brisbane has replaced Melbourne as the capital city in lockdown along with Sydney. It is unknown what the ultimate additional debt from post-2021-22 budget lockdowns will be, but it will be in the order of billions, possibly $\$ 10-20$ billion.

\section{What economics tells us about public debt}

Much of the public debt discussion is around how long it will take us to pay it back, but in a sense, as Musgrave and Musgrave (1989, p. 550) observed, 'whether we can "repay" the debt is a misdirected question'. That is because of the dirty secret of public finance- that governments can repay their existing debts as they mature by borrowing new money. That is, the debt is refunded or refinanced.

In extreme cases, lenders or bond markets may be unwilling to lend to governments, but for the levels of debt we have seen historically in Australia this has not been the case, and we do not realistically expect it to be the case in the future. The Australian Government has never defaulted on its obligations.

The burden of the debt is measured by the interest payments on that debt, and those expected interest payments should be the focus of analysis. The interest payments on debt need to be met first by governments when developing budgets, and rising interest payments can force governments to make difficult decisions, either cutting spending or increasing taxes, lest budget policy settings result in an exploding debt- 
to-GDP ratio. This is possible, depending on the key parameters of the interest rate, economic growth rate, primary budget balance to GDP and current debt-toGDP ratio. The primary balance is the actual budget balance excluding the interest payments.

The debt path is determined by the path of overall fiscal balances, or primary balances and interest bill (Escolano, 2010). A necessary condition for stabilising the ratio of public debt to GDP is (Makin \& Pearce, 2014):

$p b=\mu\left[\frac{i-g}{1+g}\right]$

where $p b$ is the primary balance to income/GDP ratio, $m$ is the debt-income ratio of the previous period, $i$ is the interest rate on government debt and $g$ is the growth in nominal GDP. Intuitively, if we assumed a primary budget balance, and noninterest expenses were equal to revenues, having interest rates higher than the rate of economic growth would mean the debt would grow faster than the economy. These so-called debt dynamics are what we capture in the numerical model used in this article.

Under certain conditions, debt-to-GDP can increase in an explosive fashion, but that is unlikely to occur in Australia. Nonetheless, we should remain concerned about the ongoing interest expense associated with the debt because government deficits could crowd out private investment, affecting future economic growth. Future generations could be burdened by inheriting a small capital stock as a result. Rudiger Dornbusch once observed:

Prospective growth of debt, even under high-deficit assumptions, does not readily assume explosive proportions. The danger inherent in continuing high deficits lies not so much in their effect on the magnitude of debt as in their current impact on the fiscal-monetary mix and thereby on the economy's rate of saving and hence, growth.

(Dornbusch 1986, p. 20)

A full analysis of the burden of debt would consider the extent to which higher interest payments imply higher taxation and the associated deadweight loss, and the implications of higher interest payments to bondholders. One substantial concern for Australia is that a large proportion of public debt is owned by foreign bondholders-hence the argument, made by Musgrave and Musgrave (1989, p. 550) in the 1980s US context, that we largely owe it to ourselves (and the interest payment is only a transfer domestically) does not hold. Over the past decade, the proportion of Australian government securities held by non-residents peaked at around 75 per cent, in 2012, and has since fallen to around 60 per cent (AOFM, 2020). 
Finally, it should be noted that inflation helps erode the real value of debt-that is, the inflation tax. Hence, any budget projection model needs to distinguish between nominal and real interest rates. Note that nominal interest rates are determined by real interest rates and inflationary expectations. The Fisher equation states:

$\mathrm{i}=\mathrm{r}+$ expected inflation

Increases in nominal interest rates associated with increases in real interest rates are costly for governments. In contrast, if the government's borrowing rate increases because of expected inflation pushing up the nominal interest rate, any inflation that occurs will provide a benefit to the government by eroding the real value of its existing debt. The nominal level of activity and the government's tax revenues expand with inflation, making it easier to service an existing stock of debt denominated in nominal terms. Consider that the bulk of Australian government debt is so denominated and inflation-indexed bonds are a relatively small component of total Australian government debt.

\section{Why future interest rates may be much higher than today}

Among the reasons for the large amount of complacency around public debt in many Organisation for Economic Co-operation and Development (OECD) economies are the historically low interest rates, both nominal and real, which have been experienced, particularly since the GFC. Historically during the twentieth century, 4 per cent was considered a real rate of return on a diversified portfolio and 1-2 per cent for fixed-interest securities such as government bonds (Fraser, 1991). Taking a wider historical perspective, Piketty (2014, p. 53) observed:

[T] he average rate of return on land in rural societies is typically on the order of 4-5 percent. In the novels of Jane Austen and Honore de Balzac, the fact that land (like government bonds) yields roughly 5 percent of the amount of capital invested $\ldots$ is so taken for granted that it often goes unmentioned.

Real interest rates, as measured by estimates of real interest rates (for bonds), have been much higher than even 5 per cent during some historical periods. According to Reserve Bank of Australia (RBA) estimates, real interest rates in Australia ranged from 7 per cent to 10 per cent for several years in the 1980 s.

But, over the past three decades, the rise of China and demographic trends have profoundly influenced inflation and interest rates. The GDR is the concept that the demographic 'sweet spot' of the past 35 or so years is set for a dramatic reversal (Goodhart \& Pradhan, 2020, p. 1). Over the past 30 years, deflationary forces were 
so strong they caused inflation to remain at or below central bank targets from 1990 onwards. Additionally, interest rates have trended downwards, with real interest rates also falling.

The GDR suggests the future will not be like the past, when baby boomers dominated the labour force and the integration of China into global manufacturing more than doubled the available labour supply. It is expected that the sweet spot of the past 35 years will turn sour due to China's shrinking workforce, reductions in the global working population, low fertility rates and increasing life expectancy. Goodhart and Pradhan (2020, p. 1) observe: 'The danger facing the global economy is that economies that have dominated global growth are facing the biggest demographic challenges.'

The decline in real interest rates over recent decades illustrates that $e x$ ante savings have exceeded ex ante investment, however, this is likely to reverse. The GDR concludes that short-term interest rates will continue to run at low real levels and be held below the increase in inflation largely due to current political contexts. However, in the longer term (that is, 10 years), interest rates will start rising and are expected to rise above the current rate of inflation. Goodhart and Pradhan (2020, p. 99) observe: 'One of our conclusions is that the yield curve, which is currently flattened to an unusual degree, will probably steepen sharply.'

The GDR states that the renewal of upwards pressure on inflation stems from a combination of a changing dependency ratio, the Phillips curve and the shifting balance between savings and investment in the private sector:

Central banks will soon enough have to revert to their normal behaviour [and] the re-birth of inflation is our highest conviction view among the effects of demographics and it is one that financial markets and policy-makers are dismissing at their own peril. (Goodhart \& Pradhan, 2020, p. 69)

So, there are good reasons to assume that both real and nominal interest rates could be much higher in future decades. Incidentally, the IGR assumes that the longrun growth rate of the economy and the interest rate on government debt are the same, at 5 per cent (The Treasury, 2021, p. 80). Possibly one of the most optimistic assumptions in the $I G R$ is that 'the 10 -year bond yield gradually converges to around 5 percent by 2039-40, consistent with long-term nominal GDP growth' (The Treasury, 2021, p. 70). But this could be far too conservative an assumption, particularly considering GDP and the large growth in money stocks seen during the pandemic, both in countries that have previously experimented with quantitative easing $(\mathrm{QE})$ such as the United States and in Australia, which adopted QE for the first time during the pandemic. 


\section{What the pandemic debt means for future budgets and debt}

This article relies on the Australian Budget Debt Projections Model (ABDPM) we have constructed to model the budget and debt over the next 40 years- the same projections period as in the $I G R$. It relies on some assumptions and projections in the $I G R$ and some we have modified to reflect an arguably more plausible scenario given economic developments in recent years. To capture the large amount of uncertainty around economic and budget parameters over the projection period, ranges are specified for key assumptions, and Monte Carlo simulations are conducted. The Monte Carlo simulations, based on 10,000 replications, are implemented using the @RISK package in Microsoft Excel. The assumed probability distribution for each parameter is the Beta-PERT distribution, which requires only the specification of a most likely value and upper and lower bounds, as is done here. That is, a variance does not need to be specified, as would be the case with the normal distribution. The Beta-PERT distribution is very popular for Monte Carlo simulations because it has a highly flexible functional form.

The assumptions of the ABDPM are set out in Table 2. Regarding the treatment of interest expenses, for simplicity, the interest expense is based on the amount of debt in the previous year. Strictly speaking, the interest expense needs to be calculated using an iterative method as it is a federal budget formulation, given that interest will be paid on new borrowings over the year, and this interest will increase the deficit, requiring some additional borrowings. But, as is presumably the case in the $I G R$ model, this complication is ignored, as is standard practice in this type of longrun budget projection model.

The model takes the IGR's primary budget balance estimates as a baseline, as they appear reasonable and reflect the government running, on average, a small deficit of 0.2 per cent on the primary balance (that is, even before accounting for net interest expenses) over the projection period.

The model accounts for the fact that over the next decade, very low borrowing costs are locked in for the Australian Government due to the amount it has already borrowed at low interest rates. The model keeps track of maturing debt and new debt, and refinanced debt is subject to the prevailing interest rates. In our view, given the macroeconomic developments and trends discussed above, the IGR is too conservative regarding the future path of interest rates (that is, a gradual transition of the 10-year bond yield to 5 per cent from the end of 2024-25 to the late 2030s). In our model, we assume a new period of higher interest rates begins in 2030, for simplicity. 
Table 2. Core ABDPM assumptions

\begin{tabular}{|l|r|l|}
\hline Parameter & Value & Justification \\
\hline Average interest rate (existing debt) & 1.5 & $\begin{array}{l}\text { Estimated based on budget data and model } \\
\text { calibration }\end{array}$ \\
\hline Average interest rate (future debt) & 5.0 & IGR assumption for long-run nominal interest rate \\
\hline Low interest rate period ends & 2030 & $\begin{array}{l}\text { Chosen to reflect a plausible year when rates } \\
\text { normalise-one that is earlier than the /GR's }\end{array}$ \\
\hline Real interest rate & 2.6 & Implied in /GR \\
\hline Expected inflation & 2.3 & Implied in /GR \\
\hline Nominal interest rate & 5.0 & IGR \\
\hline $\begin{array}{l}\text { Years before old debt matures (from } \\
\text { 2020-21) }\end{array}$ & 20 & $\begin{array}{l}\text { To approximate the maturity structure of existing } \\
\text { debt in a way convenient for modelling }\end{array}$ \\
\hline $\begin{array}{l}\text { Additional debt at end of forward } \\
\text { estimates (\$ billion) }\end{array}$ & 20 & $\begin{array}{l}\text { Best guess based on current and possible future } \\
\text { measures }\end{array}$ \\
\hline $\begin{array}{l}\text { Extra spending as of GDP in late } \\
\text { 2030s }\end{array}$ & 2 & $\begin{array}{l}\text { Arbitrary assumption chosen to acknowledge that } \\
\text { another crisis requiring fiscal stimulus response of at } \\
\text { least this magnitude will probably occur in the next } \\
\text { several decades }\end{array}$ \\
\hline
\end{tabular}

For a subset of the parameters listed in Table 2, plausible lower and upper bounds are provided for the Monte Carlo simulations (Table 3). These are based on our consideration of potential future economic developments, including the GDR and higher inflation associated with recent strong growth in money supply associated with QE.

Table 3. Lower and upper bounds for the Monte Carlo simulations

\begin{tabular}{|l|r|r|}
\hline Parameter & Lower bound & Upper bound \\
\hline Real GDP growth & 2.0 & 3.0 \\
\hline Inflation & 2.0 & 5.0 \\
\hline Real interest rate & 2.0 & 5.0 \\
\hline Variation from IGR primary balance & 0.0 & 0.5 \\
\hline Crisis spending & 1.0 & 5.0 \\
\hline Real GDP growth & 2.0 & 3.0 \\
\hline Additional debt (\$ billion) at end of forward estimates due to & 10 & 50 \\
lockdowns since 2020-21 & & \\
\hline
\end{tabular}

Using the ABDPM and the assumptions in Tables 2 and 3, the following Monte Carlo simulation results were obtained (Tables 4 and 5). Depending on the parameters of the model, future debt levels can vary in a large range. Critical metrics such as net debt-to-GDP or interest expenses as a percentage of total expenses could increase in future decades to much higher levels than currently expected. 
Table 4. ABDPM Monte Carlo simulation results (\$)

\begin{tabular}{|l|l|r|r|r|r|r|}
\hline Metric & Year & \multicolumn{1}{c|}{ Min. } & \multicolumn{1}{c|}{ Mean } & \multicolumn{1}{c|}{ Max. } & \multicolumn{1}{c|}{ P5 } & \multicolumn{1}{c|}{ P95 } \\
\hline \multirow{3}{*}{ Gross debt $(\$ b)$} & $2031-32$ & 1,504 & 1,592 & 1,669 & 1,554 & 1,625 \\
\cline { 2 - 7 } & $2041-42$ & 1,955 & 2,464 & 3,376 & 2,203 & 2,771 \\
\cline { 2 - 7 } & $2051-52$ & 2,602 & 4,029 & 7,393 & 3,220 & 5,081 \\
\hline \multirow{2}{*}{ Net debt (\$b) } & $2031-32$ & 1,044 & 1,133 & 1,192 & 1,095 & 1,164 \\
\cline { 2 - 7 } & $2041-42$ & 1,380 & 1,886 & 2,675 & 1,652 & 2,147 \\
\cline { 2 - 7 } & $2051-52$ & 1,836 & 3,277 & 6,375 & 2,534 & 4,232 \\
\hline
\end{tabular}

Note: P5 is fifth percentile, and P95 is 95th percentile.

Table 5. ABDPM Monte Carlo simulation results (percentages)

\begin{tabular}{|c|c|c|c|c|c|c|}
\hline Metric & Year & Min. & Mean & Max. & P5 & P95 \\
\hline \multirow[t]{3}{*}{ Gross debt/GDP } & 2031-32 & 40.1 & 46.2 & 50.3 & 43.5 & 48.4 \\
\hline & $2041-42$ & 32.0 & 42.4 & 53.6 & 37.3 & 47.7 \\
\hline & 2051-52 & 25.8 & 41.0 & 63.3 & 33.0 & 50.7 \\
\hline \multirow[t]{3}{*}{ Net debt/GDP } & 2031-32 & 26.8 & 32.9 & 37.0 & 30.2 & 35.1 \\
\hline & 2041-42 & 22.1 & 32.5 & 43.7 & 27.4 & 37.8 \\
\hline & $2051-52$ & 18.2 & 33.4 & 55.7 & 25.4 & 43.1 \\
\hline \multirow[t]{3}{*}{ Interest/GDP } & 2031-32 & 1.2 & 1.5 & 2.0 & 1.3 & 1.7 \\
\hline & $2041-42$ & 1.4 & 2.1 & 3.6 & 1.7 & 2.7 \\
\hline & $2051-52$ & 1.2 & 2.2 & 4.5 & 1.6 & 3.1 \\
\hline \multirow[t]{3}{*}{ Interest/total payments } & 2031-32 & 4.4 & 5.5 & 7.3 & 4.8 & 6.3 \\
\hline & $2041-42$ & 5.3 & 7.8 & 12.5 & 6.3 & 9.8 \\
\hline & $2051-52$ & 4.5 & 8.0 & 14.9 & 5.9 & 10.9 \\
\hline \multirow[t]{3}{*}{ Deficit/GDP } & 2031-32 & -2.2 & -1.6 & -1.1 & -1.9 & -1.4 \\
\hline & $2041-42$ & -3.2 & -1.7 & -0.7 & -2.3 & -1.2 \\
\hline & 2051-52 & -4.4 & -2.2 & -0.9 & -3.1 & -1.5 \\
\hline
\end{tabular}

\section{Discussion}

Debt defaults are a common result of financial crises and there comes a point when debt becomes troublesome, causing a nation to default (Reinhart \& Rogoff, 2009). If a government needs to refinance at higher interest rates in the future, it is a time bomb for future governments and generations, particularly if the GDR analysis is correct.

That said, there appears to be little chance Australia would ever default, but that is not to say we do not have to address underlying problems and focus on fixing structural problems in the federal budget. This need will become apparent, probably in the next decade. At least for the current decade, as previously noted, the Australian Office of Financial Management has locked in some low borrowing rates. 
Australians can be thankful for the fiscal consolidations that previous governmentsparticularly the Howard-Costello Government (1996-2007) and, to a lesser extent, the Hawke-Keating Government (1983-96) - undertook in previous decades because they have so far provided the Australian Government with a large amount of 'fiscal space' to respond to crises. But there are only so many crises that can allow debt to blowout before debt management becomes a large problem. Based on the analysis in this paper, we expect that will become the case in the 2030s.

Hidden in the $I G R$ is the implication that interest expenses will become a larger share of the Australian budget. They will amount to around 7 per cent of total expenses, and likely more under realistic expectations around future shocks to the economy. The model presented in this paper suggests that, in the base case, which is not much worse than the IGR's, interest expenses could end up at an expected 5.5 per cent of total expenses in 2032 and 7.8 per cent by 2042 . But the upper bounds are at around 7 per cent and 12 per cent (Table 5 and Figure 1). Consider that, before the fiscal consolidation of the late 1980s by the Hawke-Keating Government, interest expenses reached 10.8 per cent of payments and, in 1995-96, before the Howard Government's fiscal consolidation, interest expenses reached 7.6 per cent. ${ }^{3}$ Expected future interest expenses will no doubt force future governments - or should force responsible future governments - to address structural problems in the federal budget.

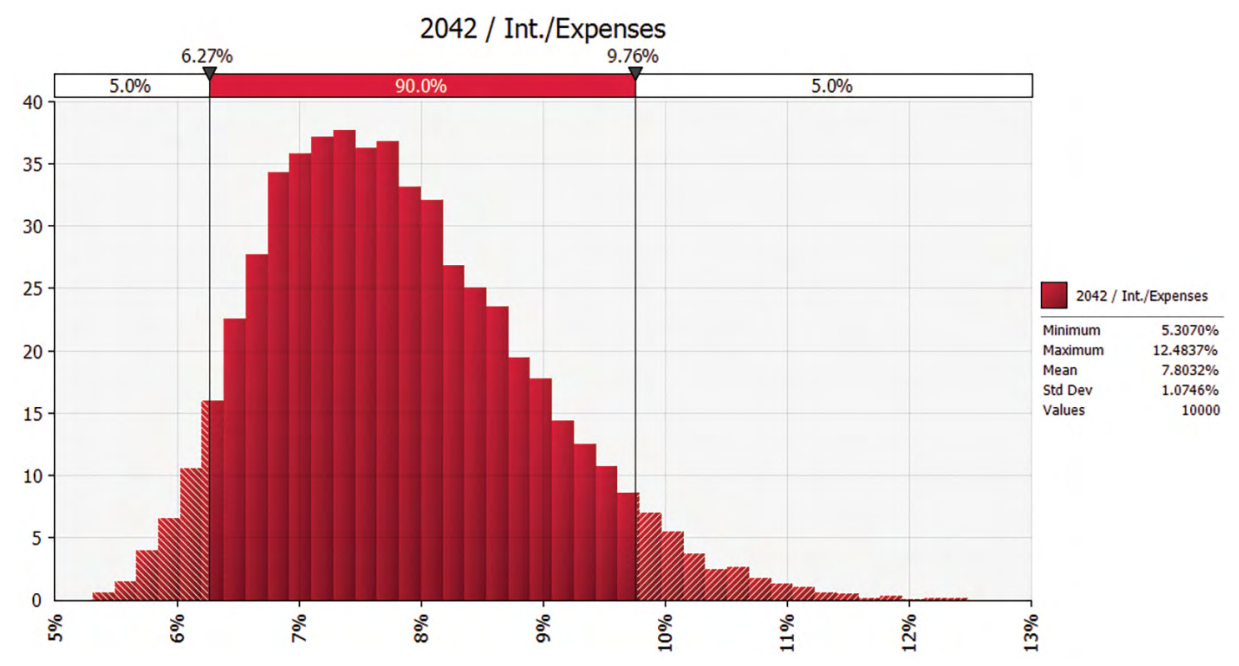

Figure 1. Probability distribution of interest expenses as percentage of total Australian government payments, 2041-42

Source: Author's calculations.

3 Estimated from 'Statement 11: Historical Australian government data' in Frydenberg and Birmingham (2021). 
As discussed above, the $I G R$ revealed that, even after we return to normal after the pandemic, the Australian Government will have, on average, a deficit in its primary budget balance. Even before the consideration of interest expenses, it appears obvious that some budget repair will be desirable. The long-run fiscal challenges facing the Australian Government are well known, particularly rising health and disability care costs, the aged pension and superannuation tax concessions. The National Disability Insurance Scheme (NDIS) is a notable risk and budget papers reveal it will surpass Medicare in dollar cost by 2024-25. Changes to all these big costs to the budget would be politically challenging, but a consideration of possible future budget outcomes suggests the government in the next two decades will need to make some hard choices to repair the budget.

So far, Australia has managed to maintain the highest credit rating despite the large debt blowout, but it could be at risk if the economy does not recover as expected and debt blows out even further.

During the Covid-19 crisis, S\&P Global's revision of Australia's AAA credit rating went from stable to negative, in April 2020. At the time, ratings agencies such as S\&P Global and Fitch stated that future outlooks remained uncertain and they had Australia's ratings on a negative outlook. During 2021, however, both agencies put Australia back on a stable outlook, averting the prospects of a ratings downgrade for the time being (see Frydenberg, 2021a).

In a worst-case scenario, if Australia does not get its public debt under control and experiences a substantially downgraded credit rating in future years, and Australiandollar-denominated bonds are seen as riskier investments, the Treasury (or, more precisely, the Australian Office of Financial Management) may need to sell bonds in foreign markets to minimise its borrowing costs. While this would be an extreme scenario and Australia is a long way from it in the foreseeable future, a reliance on foreign currency borrowing increases the risk of a future public debt crisis and potential default, as Reinhart \& Rogoff (2009) warn.

Finally, the limitations of this study should be acknowledged. It is an analysis of the potential future path of interest payments and debt, with speculation regarding what this will mean for future budget policy. We presume the necessary adjustment will need to occur through tax increases or spending reductions, given the Australian Government has already sold off its most saleable assets and its Telstra shares are locked up in the Future Fund. This has not been a welfare analysis, attempting to demonstrate which path might maximise social welfare. 


\section{Conclusions}

Projections of budgets and debt levels suggest that future Australian governments will reach levels of interest expenses that will make budget management difficult, at ratios to total expenses that have prompted fiscal consolidations in the pastfor example, the Howard-Costello fiscal consolidation from 1996-97. Future governments will face difficult choices in addressing the expected structural budget deficit. They may need to address politically sensitive budget items such as the age pension, superannuation tax concessions and the NDIS, among others.

\section{References}

Australian Office of Financial Management (AOFM). (2020). The Australian Government Securities investor base (AOFM Investor Insights No. 30). Australian Office of Financial Management. Available from: www.aofm.gov.au/investors/wholesale-investors/investorinsights/australian-government-securities-investor-base.

Bongiorno, F. (2019). 1996-1997 cabinet papers show how Howard and Costello faced a budget black hole. The Conversation, 1 January. Available from: theconversation.com/19961997-cabinet-papers-show-how-howard-and-costello-faced-a-budget-black-hole-107273.

Davies, A. \& Visontay, E. (2021). Half a million NSW workers granted Covid payments, but many remain ineligible. The Guardian, 23 July. Available from: www.theguardian. com/australia-news/2021/jul/23/half-a-million-nsw-workers-granted-covid-paymentsbut-many-remain-ineligible.

Di Marco, K., Pirie, M. \& Au-Yeung, W. (2019). A history of public debt in Australia. The Treasury. Available from: treasury.gov.au/sites/default/files/2019-03/01_Public_Debt. rtf\#: $\sim$ :text=Trends\%20in\%20Australian\%20Government\%20net\%20debt\&text= Since\%201970\%2D71\%2C\%20net\%20debt,in\%20the\%20government's\%20budget $\% 20$ position.

Dornbusch, R. (1986). Dollars, debts, and deficits. MIT Press.

Eisner, R. (1989). Budget deficits: Rhetoric and reality. The Journal of Economic Perspectives, 3(2), 73-93. doi.org/10.1257/jep.3.2.73.

Escolano, J. (2010). A practical guide to public debt dynamics, fiscal sustainability, and cyclical adjustment of budgetary aggregates (Technical Notes and Manuals, No. 002). International Monetary Fund. doi.org/10.5089/9781462396955.005.

Fraser, B. (1991). Three decades of real interest rates (RBA Bulletin-October). Reserve Bank of Australia. Available from: www.rba.gov.au/publications/bulletin/1991/oct/pdf/bu1091-2.pdf. 
Frydenberg, J. (2021a). AAA credit rating reaffirmed by Fitch (Media release, 22 February). Australian Government. Available from: ministers.treasury.gov.au/ministers/joshfrydenberg-2018/media-releases/aaa-credit-rating-reaffirmed-fitch-1.

Frydenberg, J. (2021b). NSW Covid-19 Support Package (Joint media statement with the Hon. Scott Morrison MP, Prime Minister, 13 July). Australian Government. Available from: ministers.treasury.gov.au/ministers/josh-frydenberg-2018/media-releases/nswcovid-19-support-package-0.

Frydenberg, J. \& Birmingham, S. (2021). Budget 2021-22: Budget strategy and outlook (Budget Paper No. 1, 2021-22). Australian Government. Available from: budget.gov. au/2021-22/content/bp1/download/bp1_2021-22.pdf.

Gittins, R. (2021). The real reason the budget is projected to stay in deficit for the next 40 years. Sydney Morning Herald, 6 July.

Goodhart, C. \& Pradhan, M. (2020). The great demographic reversal: Ageing societies, waning inequality, and an inflation revival. Palgrave Macmillan. doi.org/10.1007/978-3-03042657-6.

Gruen, D. \& Sayegh, A. (2005). The evolution of fiscal policy in Australia (Working/ Technical Paper 2005-04, 14 November). The Treasury. Available from: treasury.gov.au/ publication/2005-04-the-evolution-of-fiscal-policy-in-australia/2005-04-the-evolutionof-fiscal-policy-in-australia.

Guay, L., Nguyen, V., Robinson,T., Tsiaplias, S. \& Jiao, W. (2021). The Australian economy in 2020-21: The Covid-19 pandemic and prospects for economic recovery. Australian Economic Review, 54(1), 5-18. doi.org/10.1111/1467-8462.12405.

Kirchner, S. (2021). Post-pandemic debt stability dynamics are probably better than you think: The surprise takeaway from the 2021 IGR (Newsletter). Available from: stephenkirchner. substack.com/.

Makin, A.J. \& Pearce, J. (2014). Fiscal consolidation and Australia's public debt. Australian Journal of Public Administration, 75(4), 424-40. doi.org/10.1111/1467-8500.12214.

McCrann, T. (2021). Buried in Treasury's fantasia of fiscal fatuity. The Australian, 2 July.

Musgrave, R.A. \& Musgrave, P.B. (1989). Public finance in theory and practice. 5th edn. McGraw-Hill.

Piketty, T. (2014). Capital in the twenty-first century. Belknap Press of Harvard University Press. doi.org/10.4159/9780674369542.

Reinhart, C. \& Rogoff, K. (2009). This time is different: Eight centuries of financial folly. Princeton University Press. doi.org/10.1515/9781400831722.

The Treasury. (2021). 2021 Intergenerational Report. Australian Government. Available from: treasury.gov.au/sites/default/files/2021-06/p2021_182464.pdf. 
Tingle, L. \& Elton, J. (2021). Treasury estimates NSW COVID-19 lockdown costing $\$ 700 \mathrm{~m}$ a week. $A B C$ News, 13 July. Available from: www.abc.net.au/news/2021-07-13/ frydenberg-covid-support-victoria-andrews/100291000.

Wood, D. \& Crowley, T. (2020). Don't worry about the debt: We need stimulus to avoid a recession. The Conversation, 6 October. Available from: theconversation.com/dontworry-about-the-debt-we-need-stimulus-to-avoid-a-recession-147369.

Wright, S. (2021). Debt problem? Not even a big rate rise will hurt the budget. Sydney Morning Herald, 25 May. Available from: www.smh.com.au/politics/federal/debtproblem-not-even-a-big-rate-rise-will-hurt-the-budget-20210525-p57uyf.html\#: -:text=Economy\%20faring\%20better\%20than\%20 expected,over\%20the $\% 20$ next $\% 20$ two\%20years. 
This text is taken from Agenda, Volume 28 - Number 1, 2021 edited by William Coleman, published 2021 by ANU Press, The Australian National University, Canberra, Australia.

doi.org/10.22459/AG.28.01.2021.10 